\title{
Trajetória de professores das escolas multisseriadas do Munícipio de Concórdia/SC e suas práticas educativas (1950-1970)
}

\author{
Teachers' trajectory of multisseriated schools in Concórdia - SC and their educational practices
}

(1950-1970)

\author{
Trayectoria de maestros de las escuelas multiseriadas de Concórdia - SC y sus prácticas \\ educativas (1950-1970)
}

Solange Aparecida Zotti - Instituto Federal Catarinense - IFC | Cursos de Licenciatura e do Mestrado em Educação | Blumenau | SC | Brasil. E-mail: solange.zotti@ifc.edu.br | (1)orci

Francini Coelli Schneider Schwingel - Instituto Federal Catarinense - IFC | Curso de Licenciatura em Matemática | Blumenau | SC | Brasil. E-mail: francineschwingel@gmail.com |

(D) ORCID

Resumo: Concórdia/SC tornou-se município em 1934 e sua economia estava assentada na agricultura de subsistência nas pequenas propriedades rurais familiares. Nesse contexto se desenvolve uma rede de escolas multisseriadas que tem por objetivo a alfabetização da população do campo. Este trabalho apresenta a trajetória de um grupo de professores das escolas multisseriadas do Município e analisa as práticas educativas desenvolvidas por estes profissionais e que caracterizaram as escolas, considerando-se o contexto socioeconômico do município. De caráter qualitativo, foram realizadas oito entrevistas que exploraram os temas formação, planejamento, processo de aprendizagem, métodos de ensino e sistema de avaliação. As práticas educativas das escolas se caracterizaram tradicionais e a diversidade é um aspecto positivo no processo de aprendizagem, bem como o papel dos professores na comunidade.

Palavras-chave: Escolas multisseriadas. Profissão docente. Práticas educativas.

Abstract: Concordia/SC city became a municipality in 1934 and its economy was based on subsistence farming on small family farms. In this context, it developes a network of multisseriated schools that aims the literacy of the rural population. This work presents the trajectory of a teachers' group from multisseriated schools of Concordia city and analyzes the educational practices developed by these professionals and that characterized the schools, considering the socioeconomic context of the municipality. It was carried out eight interviews which explored the themes of training, planning, learning process, teaching methods and evaluation system, based on qualitative method. The educational practices of schools are traditional characterized and the diversity is a positive aspect of the learning process as well as the role of teachers in the community.

Keywords: Multisseriated schools. Teaching professional. Educational practices.

- Recebido em 12 de julho de 2019 • Aprovado em 19 de setembro de 2019 • e-ISSN: 2177-5796

DOI: http://dx.doi.org/10.22483/2177-5796.2020v22n3p795-822

Copyright @ 2019. Conteúdo de acesso aberto, distribuído sob os termos da Licença Internaonal da CreativeCommons - CC BY-NC-SA Atribuição Não Comercial (https://br.creativecommons.org/licencas/) - Permite distribuição e reprodução, desde que atribuam os devido créditos à publicação, ao autor(es) e que licenciem as novas criações sob termos idênticos. 
ZOTTI, Solange Aparecida; SCHWINGEL, Francini Coelli Schneider. Trajetória de professores das escolas multisseriadas do Munícipio de Concórdia/SC e suas práticas educativas (1950-1970).

Resumen: Concordia / SC se convirtió en un municipio en 1934 y su economía se basaba en la agricultura de subsistencia en pequeñas fincas familiares. En este contexto, se desarrolla una red de escuelas multisseriadas que apunta para la alfabetización de la población rural. Este trabajo presenta la trayectoria de un grupo de docentes de las escuelas multiseriadas dela ciudad y analiza las prácticas educativas desarrolladas por estos profesionales y que caracterizan las escuelas, considerando el contexto socioeconómico del municipio. De carácter cualitativo, se realizaron ocho entrevistas que se exploraron los temas de capacitación, planificación, proceso de aprendizaje, métodos de enseñanza y sistema de evaluación. Las prácticas educativas de las escuelas son tradicionales y la diversidad es un aspecto positivo del proceso de aprendizaje, así como el papel de los maestros en la comunidad.

Palabras clave: Escuelas multiseriadas. Profesión docente. Prácticas educativas. 


\section{Introdução}

O distrito de Concórdia, pertencente ao município de Joaçaba, localizado no Oeste de Santa Catarina, tornou-se município em 1934. A economia estava assentada na agricultura de subsistência nas pequenas propriedades rurais familiares, que se constituíram a partir do movimento migratório da segunda geração de descendentes de italianos e alemães vindos das colônias do Rio Grande do Sul, no início do século XX. Concórdia passou a receber migrantes ítalo-germânicos a partir de 1920, sendo esta considerada a terceira fase da ocupação da região e determinante no processo de expansão do modelo capitalista, caracterizado pela produção agropecuária em pequenas propriedades rurais espalhadas pelo município (AMADOR, 2015).

Duas fases antecederam a colonização da região oeste catarinense: a primeira é marcada pela ocupação dos povos nativos Kaingang e Xoklen, que partilham do mesmo espaço geográfico e vai até meados do século XIX, praticamente sem a presença portuguesa ou brasileira; a segunda tem no caboclo, que é resultante da miscigenação de luso-brasileiros, escravos africanos e nativos, o elemento central, do século XIX até o início do século XX (AMADOR, 2015).

A partir do término da Guerra do Contestado (1912-1916), inicia a fase da colonização, através da atuação das companhias colonizadoras, pelos migrantes de origem europeia e que confronta o caboclo e seu modelo econômico de subsistência. O migrante vem em busca de terras e riqueza, e na lógica do capital o caboclo é visto como desapegado do trabalho, portanto, não serve ao novo modelo (AMADOR, 2015). A propriedade sobre a terra pelo colono suplanta a visão do caboclo da terra como bem comum. Nesse sentido, destaca Comassetto et al. (2006, p. 165) que

o caboclo foi considerado um intruso e expulso do local onde habitava. Sendo obrigado a entranhar-se nos sertões não habitados, onde pudesse viver com sua roça cabocla. Porém, com o avanço das frentes de colonização, o caboclo era obrigado a deslocar-se para novas áreas, constituindo-se como 'frente da frente' de colonização, devido à colônia se organizar nas áreas habitadas antes por caboclos.

E nesse contexto que o município de Concórdia constitui-se até sua emancipação políticoadministrativa. Na época de sua emancipação, segundo Ferreira (1992), o novo município "possuía uma área de $2.754 \mathrm{Km}^{2}$, onde viviam 21.086 moradores ${ }^{1}$ ", sendo que a maioria residia e produzia no meio rural. Em 1940, a população era de 32.754 habitantes (IBGE, 1941, p. 40). Em 1950, a

\footnotetext{
${ }^{1}$ Não localizamos na página do IBGE os dados populacionais de 1934. Os dados mais antigos disponibilizados pelo IBGE são de 1940. Por isso, utilizamos a referência do autor citado para informar a população do município quando ocorreu sua emancipação. $\mathrm{O}$ autor não menciona em sua obra a fonte de pesquisa, mas, provavelmente coletou este dado de algum documento obtido junto a Prefeitura Municipal ou outro arquivo.
} 
população total atinge 48.014 habitantes, sendo que a população urbana e suburbana era de 3.742 habitantes, enquanto a rural era de 44.272 (IBGE, 1955², p. 81). Dados de 1960 apontam um total 44.761 habitantes, sendo 7.003 residentes na cidade e vilas e 37.758 residia na zona rural (IBGE, 1968, p. 116). Por fim, o censo de 1970 indica uma população de 46.063, sendo 11.125 residentes na zona urbana e 34.938 na zona rural (IBGE, 1971, p. 40). Diante destes dados, constatamos que a maior parte população até os anos de 1970 residia no meio rural e a economia era baseada na produção agropecuária, vinculada à produção agroindustrial junto S.A. Indústria e Comércio Concórdia (a popular Sadia), desde sua fundação em 07 de junho de 1944.

Essa realidade econômica e populacional impulsiona a construção de uma rede de escolas rurais, denominadas escolas isoladas, mantidas, primeiramente, pelo governo do estado. No decorrer da história, identifica-se movimentos de transferência de responsabilidade, ora o estado passa a escola para o município, ora o município passa a escola para ao estado. As escolas isoladas (multisseriadas) constituem-se na modalidade predominante de oferta do ensino primário ( $1^{\mathrm{a}}$ a $4^{\mathrm{a}}$ séries) no meio rural até 1990, quando inicia o fechamento da maioria delas e o processo de nucleação, que reuniu os alunos das escolas multisseriadas desativadas em centros maiores. A justificativa era viabilizar o atendimento de um número maior de alunos por professor, com a separação em classes de acordo com a série, a fim de elevar a qualidade do ensino e possibilitar melhor socialização dos estudantes. Por outro lado, as políticas econômicas dos anos 90 se caracterizaram pela racionalidade financeira e a defesa do Estado mínimo, sendo que o processo de municipalização e nucleação acompanham este princípio.

De acordo com Cardoso (2013), as escolas isoladas constituem-se nas antecessoras das escolas multisseriadas, pois esta nomenclatura aparece no cenário educacional após os anos de 1970. Contudo, em relação à caracterização de uma escola isolada ou multisseriada (termo que adotamos ao longo do artigo) é a mesma: estas escolas atendiam, em uma sala de aula, várias séries do ensino primário (multi $-1^{\mathrm{a}}$ a $4^{\mathrm{a}}$ séries) conduzidas por um só professor, por isso também denominadas unidocentes. O prédio escolar, muito simples, tinha uma sala de aula, cozinha e banheiros (normalmente dois, um feminino e um masculino) e uma varanda, sendo as construções de madeira e, mais tarde, de alvenaria.

O termo "Escola Isolada Municipal" permaneceu denominando as escolas multisseriadas rurais até os anos 2000. A I Conferência Municipal de Educação do Campo - COMEC (2004), do município de Concórdia - SC, aprovou a denominação "Escola Municipal do Campo", em

\footnotetext{
${ }^{2}$ Esta população era a que residia na zona urbana e suburbana, que correspondia às cidades (sedes municipais) ou às vila (sedes distritais). A população rural abrange toda a área situada fora dos limites das cidades e vilas.
} 
substituição ao termo "Isolada" (SCHIAVINI, 2018). Posteriormente, a nova denominação foi oficializada através da Lei n. 3.699, de 14 de dezembro de 2005 (CONCÓRDIA, 2005, p. 1).

Objetivamos, neste artigo, apresentar a trajetória de um grupo de professores das escolas multisseriadas do município de Concórdia/SC e analisar as práticas educativas desenvolvidas por estes profissionais e que caracterizaram estas escolas, considerando-se o contexto socioeconômico do município e as políticas educacionais de formação.

O estudo caracterizou-se pela abordagem qualitativa, por meio de pesquisa bibliográfica, documental e de campo. A pesquisa documental ${ }^{3}$ foi realizada no arquivo da Secretaria Municipal de Educação, sendo pesquisados documentos de 82 escolas multisseriadas já desativadas. Com base nas fichas de matrícula e diários de classe foram identificados 638 professores que atuaram nas escolas desde a década de 1940.

Para a realização das entrevistas ${ }^{4}$, utilizou-se como critério, que o professor/professora tivesse no mínimo 5 anos de atuação em escola multisseriada. No momento das entrevistas, conforme o Termo de Consentimento Livre e Esclarecido, o entrevistado poderia optar pela divulgação ou não de sua identidade. Neste artigo, duas professoras optaram por não divulgar seu nome, por isso foi adotado um nome fictício, informado em nota de rodapé quando da ocorrência de informações socializadas pelas mesmas.

Neste trabalho, analisamos os dados de oito (8) entrevistas, sendo seis (6) professoras e dois (2) professores, que iniciaram suas carreiras nas décadas de 1950, 1960 e 1970. Com base em um roteiro de questões semiestruturadas foram explorados temas relacionados à trajetória profissional, à organização das escolas, ao planejamento, aos métodos de ensino e ao sistema de avaliação, apresentados e analisados neste artigo.

As narrativas de professores como fonte de pesquisa vêm sendo adotadas no campo da pesquisa educacional como uma metodologia de investigação. Estas narrativas contribuem para explorar, de forma mais específica, a experiência docente em relação à organização do trabalho

\footnotetext{
${ }^{3}$ A pesquisa documental foi realizada através do projeto "História das Instituições Escolares Rurais Multisseriadas do Município de Concórdia: levantamento de fontes documentais e orais", contemplado com Bolsa PIBIC - Af /CNPq nos anos de 2016, 2017 e 2018.

${ }^{4}$ Esta pesquisa foi aprovada junto ao Comitê de Ética em Pesquisa conforme Parecer n. 2.254.704/2017 (IFC). Cabe esclarecer que o Termo de Consentimento Livre e Esclarecido previu duas situações aos entrevistados, conforme segue: "Também gostaríamos de salientar que suas informações poderão ser tratadas de forma anônima ou não, dependendo de sua escolha. Caso concorde em divulgar seu nome nas produções científicas, você assinará uma autorização, expressa através de Declaração (1) anexa a este Termo. Caso não concorde em divulgar seu nome, somente serão divulgadas as informações socializadas na entrevista, sendo que assinará a Declaração (2) anexa a este Termo" (TCLE, 2017, p. 2-3). Neste artigo, duas entrevistas são de professoras que optaram por não divulgar seu nome, por isso foi adotado um nome fictício, informado em nota de rodapé, quando da ocorrência de dados destas entrevistadas
} 
didático e outros aspectos que os documentos, muitas vezes, não evidenciam. Por isso, utilizamos a história oral como metodologia de pesquisa a fim de sistematizar as experiências dos professores, compreender suas trajetórias e suas práticas educativas, sem perder de vista a totalidade e a relação parte-todo e todo-parte. Nesse sentido, a concepção materialista histórica dialética é a norteadora da pesquisa tendo em vista o movimento real em sua totalidade, no qual o particular é explicitado no contexto socioeconômico-político, dialeticamente relacionados.

O artigo está organizado em duas seções: a primeira apresenta os professores entrevistados com ênfase em sua formação; a segunda seção aborda as práticas educativas presentes na escolas multisseriadas a partir da visão dos professores.

\section{Os professores das escolas multisseriadas e sua formação}

O contexto nacional que se configura a partir dos anos de 1930 é marcado pela transição de uma sociedade rural/agrária/comercial para uma de base urbano-industrial. A crise mundial do final dos anos de 1920 possibilitou a industrialização do país a partir da acumulação capitalista proporcionada pelo café, devido ao quase monopólio no mercado internacional. Conforme Ribeiro (1998), o reconhecimento de que a economia brasileira, centrada na agricultura e na exportação de um lado, e, do outro, a exigência de importação de produtos manufaturados, já não ofereciam condições para o desenvolvimento, fez erigir conflitos entre os dois grupos da classe dominante setor agrário-exportador e a burguesia industrial, formada, em parte, por cafeicultores descontentes com a política de valorização do café no período. Nesse contexto, o modelo de "substituição de importações", ancorado na ideologia política do "nacional-desenvolvimentismo", marca a nova fase de desenvolvimento do capitalismo no Brasil, que consolida a indústria de bens de consumo não duráveis até o início da década de 1950 e proporciona as condições para o desenvolvimento da indústria de bens duráveis até o final desta década. De acordo com Saviani (2007, p. 191), esta nova fase "implicou o deslocamento do eixo da vida societária do campo para a cidade e da agricultura para a indústria, ocorrendo, inclusive, um progressivo processo de urbanização do campo e industrialização da agricultura".

Nos anos de 1950-1960 consolida-se o processo de industrialização/urbanização num contexto de democratização político-social. Se por um lado há uma crescimento econômico significativo, por outro as disparidades sociais se agravam como resultado do processo de urbanização, que tornou-se mais acelerado a partir de 1956 em função da intensificação da industrialização. 
O processo de urbanização se apoiou no êxodo rural, provocado especialmente pela perda do trabalho no setor agropecuário devido à crise da cafeicultura e à modernização técnica do trabalho rural. Consequentemente, a busca de empregos e melhores condições de vida, pelos migrantes, provocou o inchaço das cidades que não acompanharam, no mesmo ritmo, a estruturação necessária para receber esta população em termos de moradias, escolas, saneamento básico, entre outros. As consequências foram o aumento da criminalidade, a favelização, a poluição ambiental e o aumento dos índices de desemprego. Este processo ocorreu primeiramente no sudeste do Brasil, especialmente nos estados de São Paulo e Rio de Janeiro (MIRANDA, 2020). No Sul do país o processo de urbanização não ocorreu no mesmo ritmo. Em 1950, 29,5\% da população vivia nas cidades. Este índice passou a 44,3\% na década de 1960, e somente a partir da década de 1970 o índice de urbanização chegou a 80,9\% (IBGE, 1990).

Nesse contexto, a educação escolar se torna necessária a uma quantidade maior de pessoas devido à finalidade imediata de qualificar a mão de obra para atuar na indústria e outros serviços decorrentes da urbanização. No Brasil, o estado de São Paulo é pioneiro na criação dos Grupos Escolares, com a primeira experiência em 1893. A partir dessa experiência, por sete décadas, este tipo de escola passa a atender a zona urbana ou espaços com demanda de alunos para a organização no sistema graduado e seriado, com várias classes e vários professores (SOUZA, 2006). Mesmo assim, não ocorreu a democratização do ensino primário a toda a população. Os enormes contingentes de migrantes continuaram analfabetos e os grupos escolares urbanos constituíram-se em "uma escola eficiente para o objetivo de seleção e formação da elite" (SAVIANI, 2007, p. 175).

Por outro lado, o meio rural, que se desenvolveu historicamente a partir da lógica do colonialismo, caracterizado pela "concentração da terra, exploração do trabalho com a escravidão dos negros, a servidão dos índios e o assalariamento para os brancos pobres” (SILVA, 2014, p. 79), não é contemplado nesse processo de ampliação do acesso à escola, que é pensada para o meio urbano e para a formação dos trabalhadores que irão ocupar os postos de trabalho decorrentes da industrialização. Assim, o colonialismo se reconfigura no sentido de que as relações desiguais, originadas na situação colonial, são ressignificadas no capitalismo e se estabelecem no contexto rural projetos educacionais vinculados ao fortalecimento do capital (SILVA, 2018). O resultado foi a organização de uma rede escolar voltada para a elite, ficando a população rural novamente desassistida quanto ao seu direito de escolarização, mesmo em espaços rurais com grande produção agrícola. Assim, a oferta de educação nas áreas rurais esteve vinculada a uma visão "assistencialista, tecnicista e compensatória com o objetivo de fixar os sujeitos campesinos nos seus territórios, mas em obediência à agenda urbana de desenvolvimento, configurando o Paradigma da Educação Rural 
Hegemônica (SILVA et al., 2014, p. 19-20). A lógica de que para produzir a partir da terra não precisa de estudo permanece, por isso uma alfabetização rasa é suficiente para as populações rurais, que continuam apresentando os mais baixos índices de escolaridade. Conforme Silva (et al., 2014, p. 22), "a educação ofertada atendia a modelos de sociedade que não eram os campesinos. Uma educação nos territórios rurais, para os sujeitos campesinos, mas não com eles; não de acordo com as suas especificidades $[\ldots]$ ".

O desenvolvimento da região oeste de Santa Catarina, e especificamente Concórdia, se deu a partir das pequenas propriedades rurais familiares, primeiro com produção de subsistência e, à medida que as propriedades se estruturavam, passavam a produzir excedentes para o comércio e para a agroindústria. Estava presente a concepção de uma sociedade utilitarista, articulada com apropriação dos bens privados, que orienta os descendentes de imigrantes que se estabelecem na região. Nesse sentido, a escola é vista como uma necessidade secundária e o trabalho como prioridade e meio mais eficaz de acumular riquezas. Essa concepção pode ser ilustrada através de um dizer que se tornou comum na região: "Estudo ou escola não enche barriga". Assim, a escola não é vista como possibilidade de ascensão material, e tampouco o Estado tinha preocupação com a educação da população (AMADOR, 2015). Mesmo assim, a escola isolada multisseriada estava presente na zona rural, com o objetivo de suprir a necessidade de alfabetização das crianças, o que era considerado importante pelas famílias nas comunidades.

Diversas dificuldades acompanham a existência destas escolas, que historicamente carregaram a condição de difíceis em todos os aspectos, tais como: acesso, transporte, condições físicas e materiais, alunos com pouco contato com o mundo letrado, falta de professores ou professores não habilitados, entre outros. Nesse período, a existência do professor leigo é comum e este, geralmente, encontrava-se atuando nas escolas rurais. O professor leigo exerce o magistério sem possuir a habilitação mínima exigida, que no caso, a partir de 1946, passou a ser o curso normal, de nível médio. De modo geral, lecionam em escolas localizadas em regiões rurais de difícil acesso e também apresentam a dificuldade de residirem distante de escolas ou faculdades para realizar sua formação (AUGUSTO, 2010, p. 1). Também, mesmo que houvesse professores habilitados, havia a dificuldade de deslocamento e de condições de trabalho na zona rural, e isso levava o professor a escolher, se tinha a oportunidade, a zona urbana ou os locais de melhor acesso. Por isso, muitos professores leigos eram moradores das comunidades, sendo escolhidos a partir de um reconhecimento social pelas suas capacidades e envolvimento com a mesma.

A formação de professores, a partir do Decreto-lei $n^{\circ}$ 8.530, de 2 de janeiro de 1946, passou a ser realizada, oficialmente, na Escola Normal, que tinha por objetivo a formação docente para as 
escolas primárias; habilitar administradores escolares e desenvolver e propagar os conhecimentos e técnicas relativas à educação da infância. Para atender a estes objetivos o Curso Normal foi organizado em dois ciclos, ambos profissionalizantes. O $1^{\circ}$ ciclo destinava-se a habilitar os professores leigos já atuantes (o que era comum) e formava os regentes de ensino primário, com duração de quatro anos (Curso Ginasial), que, além das disciplinas de conhecimentos gerais característicos do curso ginasial, já tinha algumas disciplinas de conteúdos específicos para a formação pedagógica. Esta foi a modalidade que formou a maioria dos professores para atuar no PréPrimário e Ensino Primário. O $2^{\circ}$ Ciclo, com três anos de duração, formava os professores primários e consistia numa espécie de especialização para estudantes advindos do Curso Ginasial. Possuía um currículo voltado para a formação docente, com ênfase em disciplinas pedagógicas, e permitia acesso a cursos superiores da faculdade de Filosofia, para a formação de professores das áreas específicas (BRASIL, 1946).

Com a LDB, Lei n. 4.024, de 20/12/1961, a formação de docentes para o ensino primário, no Artigo 53, conservou a organização anterior, em termos de duração e divisão dos estudos, sendo que far-se-ia: a) em escola normal de grau ginasial (mínimo de quatro séries anuais com disciplinas obrigatórias do curso secundário ginasial e preparação pedagógica); b) em escola normal de grau colegial (mínimo três séries anuais em prosseguimento grau ginasial). O grau ginasial expediria diploma de regente de ensino primário; o colegial de professor primário (BRASIL, 1961). A Lei 5.692/1971 extinguiu as escolas normais e a formação passou a ser realizada em uma habilitação do ensino de $2^{\mathrm{o}}$ grau, o Magistério, que passa a ser a mínima exigida para o ensino de $1^{\mathrm{o}}$ grau, da $1^{\mathrm{a}}$ a $4^{\mathrm{a}}$ séries (BRASIL, 1971)

É nesse contexto que os professores das escola multisseriadas entrevistados iniciaram suas carreiras no município de Concórdia e o que identificamos aponta para a dificuldade de professores com formação, especialmente nas décadas de 1950 e 1960. Esta situação levava o poder público a convidar professores leigos para assumir as aulas no ensino primário, especialmente da zona rural. À medida que permaneceram na profissão, buscaram, por iniciativa própria ou por incentivo do poder público, a formação exigida para atuar no ensino primário.

A falta de professores com formação levava as autoridades municipais a convidarem pessoas, geralmente mulheres, bem relacionadas na comunidade e que tinham um mínimo de condições para ensinar a ler e a escrever, além dos conhecimentos básicos de matemática, considerados importantes no meio rural. Este era o objetivo principal da escola multisseriada rural: alfabetizar as populações que viviam do cultivo da terra. A professora Darcy Dalto Rubini ${ }^{5}$, uma das professoras mais antigas

\footnotetext{
${ }^{5}$ Entrevista realizada em 11/07/2018. Na época a entrevistada tinha oitenta e sete anos.
} 
do município, relata que estudou até os doze anos e completou a $3^{\text {a }}$ série primária: "Queria estudar para ser freira, mas tive que deixar de ir na aula para trabalhar'. Começou a dar aulas em 1958, a convite do prefeito Fioravante Massolini (1956-1961 - eleito): "o prefeito pediu para meu marido se eu não podia ser professora. Disse, olha, ela não tem muito estudo, mas diz para ela vir que vamos fazer uma prova” (fala do prefeito). E foi assim, fez a prova e passou a atuar na Escola Isolada Rui Barbosa, por onze anos, até 1969.

Três dos professores entrevistados iniciaram suas carreiras na década de 1960 e todos cursaram o Normal nos moldes da legislação decorrente da Lei Orgânica do Ensino Normal (BRASIL, 1946) e da LDB (BRASIL, 1961).

O professor Ernesto Schiavini ${ }^{6}$ cursou o Normal de férias, de grau ginasial, um tipo de curso destinado à reciclagem de professores, pois também começou a trabalhar por indicação apenas com o ensino primário concluído. Mais tarde cursou o Normal de grau colegial que acontecia no Colégio São José no munícipio de Concórdia. Este Colégio, fundado em 1939 pela Congregação São José, supervisionada pela Madre Maria Felicidade, abrigou o primeiro curso para a formação de professores de Concórdia e região (SOLIGO; SANTOS, 2005). O professor iniciou sua carreira em 1964 e lecionou até 1995, por trinta e um anos, sempre em escola multisseriada. Relatou que "tinha muito apoio da comunidade, as crianças gostavam [da escola, das aulas]”.

Em relação à formação continuada, o professor Ernesto considerava "muita boa a orientação da prefeitura e do estado. [...] davam todas as orientações que precisavam e cursos relacionados ao trabalho, sempre reciclando". Ocorriam reuniões mensais com os professores das escolas multisseriadas, que recebiam as orientações e planejavam em conjunto. Ferri (1994) também identificou que a reunião era o momento de encontrar os pares, além do professor cumprir, junto à Secretaria de Educação, as várias tarefas burocráticas, como as estatísticas, levantamentos, controle de frequência e avaliações dos alunos. A expectativa era encontrar respostas para as dificuldades de aprendizagem dos alunos, resolver questões relacionadas à melhoria da infraestrutura da escola, que tinha a parceria da Associação de Pais e professores (APP), mas que necessitava a colaboração e os encaminhamentos da administração municipal. Além disso tudo, já que estava na sede, era preciso resolver seus problemas particulares, como ir ao banco, fazer compras, resolver pendências pessoais. Pelo relato do professor e da autora, a reunião mensal era o único momento para a troca de experiências, o planejamento com os pares e para resolver as inúmeras necessidades da escola. Muitas demandas para tão restrito tempo, mas considerado importante pelos professores para o andamento do trabalho na escola multisseriada.

\footnotetext{
${ }^{6}$ Entrevista realizada em 04/07/2018.
} 
A professora Maria ${ }^{7}$ fez o Curso Normal não frequentado, através de um convênio entre o estado e a prefeitura para reciclagem de professores que não tinham habilitação. Os professores recebiam o material, estudavam em casa e prestavam provas presenciais que aconteciam no Colégio São José. Segundo a entrevistada, um grande grupo de professores da região fez este curso, uma espécie de curso a distância. A professora lecionou de 1965 a 1972, por sete anos. Em seu relato conta que foi convidada para dar aula na escola da comunidade rural de Santa Terezinha que não tinha professora, pois a anterior tinha se aposentado: “[...] vai lá e vai dar aula. Estava fazendo o ginásio no Olavo [na época Colégio São José], [...] sem orientação nenhuma, vai lá e vai da aula."

A professora Joana ${ }^{8}$ também cursou o Normal e iniciou o Curso de Pedagogia, mas não concluiu. Atuou em escola multisseridas de 1966 a 1989, por 23 anos. A professora destacou que " $O$ professor de hoje não é valorizado, na minha época ele era valorizado". De fato, "até a década de 1960, a carreira do magistério era representada como carreira "nobre" que, embora mal remunerada, era adequada às jovens de classe média vocacionadas para o magistério" (MARAFELLI; RODRIGUES; BRANDÃO, 2017, p. 986).

$\mathrm{Na}$ sequência, apresentamos quatro professores, sendo um homem e três mulheres que iniciaram suas carreiras na década de 1970. O professor Nilo Lückemeier ${ }^{9}$ concluiu o Curso de Magistério (que habilitava para lecionar de $1^{\mathrm{a}}$ a $4^{\mathrm{a}}$ em nível de $2^{\circ} \mathrm{Grau}$ ) em 1983, no Colégio Estadual Professor Olavo Cecco Rigon ${ }^{10}$, mas já atuava como professor desde 1974 na Escola Felipe Schuwten $^{11}$ (1974-1997). Atuou também na Escola Isolada de Lajeado Crescêncio (1980-1997) ${ }^{12}$, totalizando 24 anos em escola multisseridas.

O professor relatou como se tornou professor:

Fui procurado pelo prefeito da época de Concórdia em $1973^{13}$, por que não havia professores, eu não escolhi ser professor eles me escolheram, porque na falta de professores, ai comecei a trabalhar com o ginásio normal feito né, porque o ginásio normal preparava o professor já, então já sai [...] preparado pra trabalhar.

\footnotetext{
7 Trataremos esta professora apenas como Maria, pois a mesma, quando da realização da entrevista (14/03/2018), optou no TCLE por não divulgar seu nome completo, apenas as informações coletadas.

${ }^{8}$ Trataremos esta professora com o nome Joana, pois a mesma, quando da realização da entrevista (16/04/2018), optou no TCLE por não divulgar seu nome completo, apenas as informações coletadas.

${ }^{9}$ Entrevista realizada em 18/07/2018.

${ }^{10}$ Antigo Colégio São José. Passou a denominar-se Escola Estadual Professor Olavo Cecco Rigon em 1983, em homenagem ao professor Olavo Cecco Rigon. A Portaria E - 017 SED, de 28 de março de 2000 alterou a denominação para Escola de Educação Básica Professor Olavo Cecco Rigon.

${ }^{11}$ Esta escola, na época pertencia ao município de Concórdia e se localizava no Distrito de Arabutã, que veio a tornar-se município em 1991. A escola então passou a pertencer ao novo município.

${ }^{12}$ A escola de Lajeado Crescêncio e outras escolas passaram pelo processo de nucleação em 1997.

${ }^{13}$ Prefeito Substituto Adílio Hilário Mutzenberg - 19/12/1970 a 31/01/1973.
} 
[...]Daí prestei concurso [...] na mesma semana que o prefeito me procurou e passei né. [...] Continuei como professor porque a comunidade não me deixou mais sair. [...]. Após eu ter casado a comunidade fez uma casa para mim morar, para não sair, eles não queriam que eu saísse, e fiquei lá até a escola ser nucleada", em 1997.

A professora Terezinha Kleber concluiu o Curso Normal no Colégio Estadual Celso Ramos (Joaçaba/SC) em 1973. Realizou o concurso em 1974 no município de Concórdia e por 27 anos atuou na Escola Isolada de Lajeado Paulino. Um aspecto que destacamos da entrevista, que se repete em todas as demais, é o acolhimento da comunidade para com a professora, que normalmente morava na casa de uma família. A grande maioria dos professores, no período estudado, morava na comunidade ou andava muitos quilômetros para chegar até a escola. Muitas famílias hospedavam os professores sem, muitas vezes, cobrar nada por isso. Outras vezes a comunidade construía uma pequena casa ao lado da escola para o professor.

A relação professor/comunidade foi mencionada por todos os entrevistados para além do trabalho como "professor da escola". A importância e papel do professor extrapolava sua atividade no contexto da escola, pois era um ponto de referência, participando diretamente da vida da comunidade e auxiliando em suas demandas, conforme afirma Arroyo (2005, p. 15):

[...] A figura da professora e do professor quando mora junto às populações é uma figura que extrapola seu papel escolar: é conselheiro, guardião da cultura e da memória, organizador da comunidade e dirigente... Uma figura humana com funções, saberes e habilidades múltiplas.

A professora Neusa Salete Bombassaro concluiu o Curso Normal, também no Colégio São José, em 1971. Atuou como professora de 1974 a 1989, por 15 anos, todos em escola multisseriada. Questionada sobre a existência de formação continuada no período em que atuou, destacou a importância dos encontros mensais na Secretaria de Educação e dos cursos de formação:

Eram uma vez por mês, a gente tinha reunião, as vezes tinha curso também, na metade do ano [...] Era muito bom quando vinha as professoras de fora, ainda mais a alfabetização que era o que mais a gente precisava, porque alfabetizar uma criança não é brincadeira.

O desafio da alfabetização nas escolas multisseriadas é algo reforçado pelos professores. A queixa é a dificuldade de dar atenção aos alunos da $1^{\mathrm{a}}$ série, tendo mais três turmas/níveis para atender e todas as demais atividades de organização da escola.

A professora Salete Ana Sacomori Lusa concluiu o Curso de Magistério (habilitação para lecionar de $1^{\mathrm{a}}$ a $4^{\mathrm{a}}$ em nível de $2^{\circ}$ Grau) em 1980, conforme designava a Lei 5692/1971 (BRASIL, 1971). Já atuava desde 1977 na Escola Isolada Suruvi, encerrando a carreira em 2008, com 31 anos de trabalho. Em relação à formação inicial e continuada a professora destaca um aspecto que foi repetido 
por outros professores: primeiro a dificuldade, da época de formação em nível superior; segundo o esforço para vencer as dificuldades frente o compromisso que assumiam com os alunos e as comunidades onde atuavam. A professora reconhece que quando assumiu a docência na escola multisseriada percebia que não tinham o preparo adequado, mas que ao longo da atuação foi buscando aperfeiçoamento e, assim, constituiu-se professora. Questionada sobre as dificuldades enfrentadas ao logo da carreira, a mesma expõe sobre os desafios inerentes a característica das escolas multisseriadas, de atuar como professora e desempenhar todas as demais tarefas para o funcionamento da escola.

Ferri (1994, p. 92) destaca que a formação em serviço dos professores de escolas multisseriadas era "episódica, seja na forma de cursos, seja na forma de reuniões pedagógicas mensais" [...]. E conclui: "Parece-nos claro que tão importante quanto à definição de uma proposta pedagógica é o trabalho de formação em serviço que possibilite um refletir da prática do professor, de maneira que o auxilie na sua tarefa junto às crianças”. Esta era a expectativa dos professores entrevistados quando se referiam ao assunto formação continuada.

Nos relatos constatamos que, para atender as escolas multisseriadas, a escolha dos professores ocorreu por indicação dos prefeitos, pois não havia demanda de profissionais suficientes e com a formação designada pelas leis do período, no caso o Decreto-lei n 8.530/1946 e, posteriormente, a Lei de Diretrizes e Bases de 1961. A falta de professores com formação levava as autoridades a convidarem pessoas da comunidade que entendiam poder ser professor, sem critério específico para a escolha. Ao mesmo tempo, este reconhecimento da capacidade de assumir a função de professor pelas autoridades e pela comunidade, é o fator primordial para a permanência na profissão e a busca da formação profissional nos cursos Normal e, posteriormente, Magistério.

Todos os professores que iniciaram suas carreiras na década de 1970 frequentaram o Curso de Magistério, que habilitava para a docência de $1^{\mathrm{a}}$ a $4^{\mathrm{a}}$ série, sob a vigência da Lei 5.692/1971. A maioria cursou no Colégio São José, dedicado à formação de professores em nível médio, no município, desde 1939. Dois professores concluíram sua formação na década de 1980, apesar de terem iniciado suas carreiras ainda na década de 1970.

\section{Práticas educativas nas escolas multisseriadas}

As escolas multisseriadas, localizadas junto às comunidades do meio rural, muitas distantes da sede do município, historicamente se caracterizaram precárias e com dificuldades, tanto em termos de estrutura física e material, como em relação às limitações didático-pedagógicas. Nesse sentido, 
Ferri (1994), ao caracterizar em sua pesquisa as escolas multisseriadas das redes de ensino da região de Concórdia, menciona que estas carregavam o "status" de difíceis em todos os aspectos: acesso, transporte; condições físicas e materiais; alunos com dificuldades em função do pouco acesso a livros ou fontes de informação; a pouca participação dos pais no acompanhamento escolar do filhos por serem analfabetos ou porque o trabalho impedia o acompanhamento do processo escolar dos filhos; as inúmeras tarefas do professor que o impossibilitava de dedicar-se integralmente a tarefa de ensinar; as condições de formação do professor que, com poucas exceções, não foi além do Curso Normal ou Magistério, em nível médio.

A multisseriação, na maioria das realidades e tempos, foi uma decisão das secretarias de educação, em função do número de alunos reduzido para formar uma turma série/ano. Contudo, ainda que pese o número de alunos, as escolas multisseriadas foram organizadas para atender a determinada classe social, historicamente trabalhadores rurais vinculados a latifúndios ou, como no município de Concórdia, os filhos dos colonos, donos de pequenas propriedades rurais, que produziam a partir do trabalho familiar e, vinculados ou não à agroindústria sadia, através do sistema de integração ${ }^{14}$, para a criação de suínos e aves.

A escola multisseriada poderia funcionar em um ou dois turnos, dependendo do número de alunos, mas a maioria funcionou em um único turno. No caso de dois turnos, geralmente as turmas eram divididas pela proximidade de níveis em $1^{\mathrm{a}} \mathrm{e} 2^{\mathrm{a}}$ séries, geralmente à tarde, em função dos alunos serem menores; $3^{\mathrm{a}}$ e $4^{\mathrm{a}}$ séries, geralmente de manhã.

O desafio de atender quatro turmas, de séries/níveis diferentes, levava os professores a criar estratégias, a começar pelo quadro de giz, o principal instrumento disponível para o ensino. O professor Nilo destaca que o quadro era enorme e cobria toda a parede, sendo o mesmo dividido em quatro partes. Como era necessário começar com a orientação para uma série, as demais desenvolviam alguma atividade de forma independente. Nesse caso, a leitura ou atividades copiadas de livros ou outro material didático (apostilas) eram soluções para ocupar os alunos enquanto o professor explicava o conteúdo ou a tarefa para uma das séries.

Conforme o professor, outra estratégia era aproveitar os alunos mais preparados para auxiliar na tarefa de ensinar os menores ou aqueles com maiores dificuldades de aprendizagem. Segundo o

\footnotetext{
${ }^{14}$ No sistema de integração, a empresa fornece todos os insumos (aves, suínos, alimentação, medicamentos, etc) e a assistência técnica. O produtor participa com a disponibilidade da força de trabalho, que envolve toda a família, sem jornada de trabalho específica (trabalha em média $12 \mathrm{~h}$ por dia) e sem nenhum vínculo que lhes possibilite alguma direito social ou renda mínima, como os operários da agroindústria. A agroindústria determina o preço mínimo pelo lote de frango ou suíno abatido e o integrado não tem autonomia no processo de produção, embora seja o proprietário formal dos meios de produção.
} 
professor, as meninas eram melhores para esta tarefa: "o quarto ano [auxiliava], principalmente as meninas, porque as meninas... é mulheres, sabe são melhores professores do que homens né? Então as meninas já estavam muito bem preparadas, elas ajudavam a ensinar o primeiro ano ali, então isso andava muito”. Este depoimento evidencia duas questões: a presença de resquícios do ensino mútuo (Método Lancaster ou monitorial) e a visão de que a mulher é a mais preparada para educar ou ensinar crias pequenas.

Em relação à primeira questão, no Brasil, o ensino mútuo esteve presente nas escolas de primeiras letras, oficialmente, a partir da Lei do Ensino Primário de 1827. Joseph Lancaster (17781838), no final do século XVIII, na Europa, idealizou o método que consistia em aproveitar os alunos que se destacavam como monitores, responsáveis por contribuir para o ensino do restante do grupo (SAVIANI, 2007). Nas escolas multisseriadas, os alunos que tinham maior facilidade de aprendizagem e concluíam as atividades em menor tempo contribuíam com o ensino dos demais, conforme também identificou Ferri (1994, p. 55): “As crianças que terminam suas atividades e aguardam a orientação da professora para continuar seus afazeres da série, podem ajudar os colegas de sua série ou fazer uma leitura extra ou outro exercício qualquer".

A preocupação dos professores com a alfabetização dos alunos da $1^{\mathrm{a}}$ série foi recorrente nas entrevistas. Esta tarefa exigia uma dedicação mais exclusiva, o que não era possível frente a necessidade de atendimento das diferentes séries e demais tarefas que competia ao professor. Ferri (1994) enfatiza que atender quatro séries ao mesmo tempo era tarefa trabalhosa, e que as crianças de $1^{\mathrm{a}}$ série, em processo de alfabetização, eram as mais prejudicadas, pois o professor não conseguia dar o acompanhamento necessário. E Santos (2015), por outro lado, destaca a dificuldade no ensino dos maiores, que acabavam não tendo tarefas ou atividades específicas que os possibilitasse progredir nos momentos que o professor atendia os alunos menores (SANTOS, 2015). Diante dessas condições, o professor solicitava auxílio dos alunos da $4^{\text {a }}$ série para "tomar a leitura" ou ajudar nas tarefas escritas dos alunos em processo de alfabetização.

Em pesquisa sobre práticas de alfabetização em turmas multisseriadas, Sá e Pessoa (2015) também identificaram, observando 12 jornadas de aula de uma professora, que a mesma, frequentemente, solicitava que alguns alunos auxiliassem os outros nas diferentes atividades, bem como verificaram que o pedido de auxilio era acompanhado de orientações para a condução da ajuda, como não dar "respostas prontas" para as crianças. Destacam que, em muitos momentos, "a intervenção das crianças, ao auxiliar os demais colegas reproduzia, de alguma maneira, a conduta diretiva da professora [...]" (SÁ; PESSOA, 2015, p. 13). Essas práticas, exemplificam que o ensino na escola multisseriada não é tarefa apenas do professor, os alunos também ensinam, formam uma 
espécie de microssociedade, na qual cada aluno vai se ajustando para a realidade do outro, aos poucos vão trocando informações, conhecimentos, experiências, e aprendem uns com os outros, de uma forma espontânea (SANTOS, 2015) e também direcionada pelo professor.

Em relação à condução da aula, a professora Salete e a professora Neusa expuseram que, geralmente, explicavam determinado conteúdo comum a todas as séries e depois distribuíam tarefas diferenciadas, de acordo com os diferentes níveis. Na prática destas professoras há uma tentativa de adequar a metodologia de ensino à realidade da escola multisseriada, entendendo a turma como um grupo de crianças que podem ser ensinadas de forma coletiva, independente da série. Entretanto, as atividades continuam compartimentalizadas, seguindo a lógica da escola seriada que agrupa as pessoas por idades, como se não fosse possível a aprendizagem através da interação entre as diferentes séries (FERRI, 1994).

Estes conteúdos, de acordo com a professora Salete, sempre foram prescritos pela Secretaria de Educação para cada série/matéria a ser ensinada, uma espécie de listas de conteúdo, conforme expôs: "De listas, sempre foi né, tinha por isso [...] as reuniões, os treinamentos, os cursos, né o que a gente trabalha, os temas a ser trabalhado, né... pra ser todo mundo mais ou menos né...[igual] '. E segue explicando, a partir de um exemplo, o motivo desta organização e planejamento conjunto nas reuniões mensais:

[...] porque se um aluno fosse pedir transferência por exemplo, o meu daqui de Suruvi fosse pra Paulino [nomes das comunidades], pra chegar lá pra gente tá trabalhando mais ou menos né, porque as vezes, por exemplo, [...] em março nós vamos trabalhar sobre a água né, em ciências, de repente a Tere [professora] lá vai trabalhar sobre plantas, daí o meu aluno daqui vai pra lá, ele vai daí não vai pegar o que ela trabalhou lá né $[\ldots]$.

E contextualiza a realidade da zona rural que justificava a dinâmica da organização dos conteúdos nas escolas multisseriadas do município:

[...] porque tinha muitos empregados, agregados naquele tempo, pessoas que trabalhavam muito na agricultura, por isso que agora, fechou a escola, porque quase não tem né, a maioria vai trabalhar na cidade, mas antes tinha aviários, chiqueiros, e dai existia muitos empregados, daí eles mudavam sabe, seguido, de um ano aqui, dois meses lá, três ali....

Ainda, em relação à condução da aula, os demais professores expuseram que explicavam o conteúdo de cada série, não necessariamente o mesmo tema/assunto. Após, repassavam a atividade correspondente para os alunos desenvolverem individualmente e seguiam para a próxima série, ou seja, uma prática baseada na organização das turmas seriadas e que tornava o trabalho do professor ainda mais desafiador. Nesse sentido, Ferri (1994, p. 70) muito bem sintetiza esta realidade: 
O esquadrinhamento e a organização no tempo e no espaço que preveem sub-divisões cada vez maiores, seja nos programas escolares (ordenação vertical e horizontal de cada conteúdo), seja na duração pré-fixada para a realização de cada aprendizagem, os momentos estanques de planejar, ensinar, avaliar acabam por inviabilizar o trabalho da classe multisseriada que se vê multiplicada por quatro.

Uma fila para cada série...

Um planejamento para cada série...

Quatro divisões no quadro para giz: uma para cada série...

Um plano de curso para cada série...

Um conteúdo, uma atividade para cada série...

Livros didáticos... Um para cada disciplina, cada disciplina para uma série...

Esta organização, ancorada no princípio da racionalidade, através de normas e regulamentos que condicionam a prática pedagógica, não levou em consideração as peculiaridades das classes multisseriadas. Os professores, também condicionados a uma hierarquia, que se estabelece a partir da Secretaria de Educação através dos supervisores e orientadores, não questionam e cumprem as normas instituídas e os conteúdos prescritos, mesmo frente as dificuldades que esta organização impõe (FERRI, 1994).

Diante dessa organização da escola, a prática pedagógica tradicional predominava em relação aos conteúdos e a própria interação entre o professor/alunos, bem como entre as diferentes séries. A sala de aula, apesar de ser um único espaço, é dividida em classes/séries, na qual o professor explicava o conteúdo ou a atividade destinada a cada uma. Aos alunos cabia ouvir atentamente e na sequência aplicar os exercícios. Ensinar é repassar os conhecimentos, numa progressão lógica estabelecida pelo professor. A aprendizagem é receptiva e mecânica, sendo enfatizado os exercícios, a repetição de conceitos, o treino, enfim a memorização para que o aluno responda de forma semelhante ao que lhe foi transmitido pelo professor (LIBÂNEO, 1984).

A disciplina, enquanto comportamento adequado, inclusive exigida pelos pais, é outra característica enfatizada pelos entrevistados, como algo muito positivo. Afinal, cada série precisava estar em silêncio enquanto o professor se dirigia a outra. De acordo com Ferri (1994, p. 14), nas escolas multisseriadas, "para pais e professores, o perfil ideal do aluno é o de uma criança obediente, dócil, honesta, responsável e disciplinada, pois estas são, também, características indispensáveis para o ‘trabalhador'”. Ainda de acordo com Libâneo (1984, p. 10), na relação professor-aluno,

Predomina a autoridade do professor que exige atitude receptiva dos alunos e "impede qualquer comunicação entre eles no decorrer da aula. O professor transmite o conteúdo na forma de verdade a ser absorvida; em consequência, a disciplina imposta é o meio mais eficaz para assegurar a atenção e o silêncio.

O professor Nilo Lückemeier (atuou de 1974-1997) defendeu o trabalho pedagógico tradicional, no sentido de que as iniciativas cabiam ao professor, que deveria transmitir o 
conhecimento, expondo as lições a cada série, seguindo uma gradação lógica dos conteúdos, conforme a orientação da Secretaria de Educação. Após a exposição/explicação do professor cabia aos alunos aplicar atentamente os conteúdos através de exercícios, que se limitavam, muitas vezes a reprodução de informações, a fim de demonstrar se aprendeu, se assimilou ou não o conhecimento. A correção dos exercícios é outro aspecto importante no sentido de confirmar se os alunos assimilaram o conteúdo para passar ao novo. A correção dos exercícios, no quadro ou oralmente, com a participação dos alunos, também era uma forma de revisar conteúdo ensinado. O professor é a autoridade e aos alunos cabe, com obediência e disciplina ouvir as explicações e aplicar os conhecimentos transmitidos pelo professor (SAVIANI, 2007).

A concepção pedagógica defendida pelo professor fica evidenciada na crítica aos encaminhamentos, considerados "imposições", da Secretaria de Educação ao trabalho dos professores:

Nunca, nós nunca se sentimos preparados porque quando tu estava mais ou menos fazendo trabalhos, quando tu via o crescimento dos alunos, porque a gente trabalhava só tradicional, e hoje ainda se eu vou para a sala de aula eu trabalho tradicional, porque o aluno aprende tradicionalmente. [...] então a gente usava sempre o tradicional, quando viu ele crescendo as secretarias impunham qualquer coisinha aqui pra te atrapalhar, isso era verdade. (grifo nosso).

O que na visão do professor era imposição correspondia a metodologias que fugiam ao ensino tradicional e isso era mais uma dificuldade dentre as diversas que a natureza de escola multisseriada apresentava. Esta fala não é exclusiva deste professor, no decorrer das entrevista aparecem outras menções referentes à pressão que os professores sentiam em relação às cobranças e encaminhamentos da Secretaria de Educação. Se pode constatar que não é somente uma questão de "resistência à mudança”, mas que estes professores precisavam organizar o trabalho pedagógico de forma solitária e as orientações externas nem sempre eram compatíveis com a realidade e as condições que dispunham.

Quanto aos materiais disponíveis, todos os professores destacaram a precariedade, como expôs a professora Terezinha: "É porque o nosso material era o quadro e o giz né, não tinha outra coisa, e a gente trabalhava, [...] tinha o livro texto [...]”. As crianças não podiam escrever nos livros, então "eu enchia um quadro, passava tudo os textos, escrevia tudo os exercícios, escrevia os texto, escrevia os problemas, história, geografia, ciência você usava só o quadro, ou na época cartaz. Cartolina não tinha, ia comprar, não ganhava, pincel também não”. Por este e outros depoimentos dos demais professores, se identifica que os professores, quando possível, compravam materiais para utilizar com os alunos em sala de aula. Uma cartolina e pinceis tinham um valor imenso, frente a precariedade de materiais diversificados disponíveis. 
Como exemplo dessas dificuldades e como os próprios professores buscavam resolvê-las, o professor Ernesto relatou que comprou um mimeógrafo com seu dinheiro e informou a secretaria, que o ressarciu do valor quando o professor deixou a escola. A professora Darcy, que iniciou sua carreira na década de 1950, utilizava os livros de quando foi à escola para preparar as aulas. Outra alternativa, encontrada pela professora Maria, foi o uso do rádio, recebido da Igreja Matriz do município, para as aulas de ensino religioso: "[...] tinha um programa de catequese muito bom, catequese da matriz, ai era 3 horas da tarde tu ligava e era aula de ensino religioso [...]”. Os professores também destacaram a elaboração de projetos vinculados ao meio rural, como a horta para fins didáticos, mas que era também necessária para complementar o lanche.

Todos os entrevistados expuseram que o papel do professor ultrapassava as tarefas pedagógicas, a começar pelo atendimento das quatro séries. Quem assumia uma escola multisseriada tinha conhecimento do trabalho que deveria desenvolver. As tarefas de limpeza, merenda e organização, que nas demais escolas são desempenhadas por outros profissionais, nas multisseriadas eram executadas pelo professor e seus alunos, de forma colaborativa e, esporadicamente, contavam com a colaboração dos pais e da comunidade. Uma estratégia utilizada era organizar, para a semana ou para cada dia, a escala de tarefas dos alunos: fazer o lanche, limpar a cozinha, limpar a sala de aula e os banheiros, entre outras tarefas.

Os professores ressaltaram o papel educativo das diversas tarefas de organização da escola multisseriada que eram executadas coletivamente, contrariando a lógica da organização seriada das aulas, que dividia os alunos e os momentos pedagógicos, dificultando inclusive a interação entre eles. Nos demais momentos era comum as crianças brincarem e executarem as tarefas de manutenção da escola juntas, sem diferenciação de série ou idade. Contudo, a divisão das tarefas de acordo com o gênero estava presente. As meninas eram convocadas para as tarefas "domésticas" e de atuação como "professoras" junto as crianças menores. Há um reforço ao papel da mulher como dona de casa e professora, vinculado ao papel de mãe. Almeida (2004), em pesquisa que discute a feminização do magistério destaca que, já no final dos oitocentos, logo após a República, se estruturou e persistiu, pelo menos até os dois primeiros terços do século $\mathrm{XX}$, a visão da vocação feminina para a educação da infância. Às mulheres é atribuída a sagrada missão de educar os filhos, o que se estende ao espaço da escola como uma destinação natural em vista das qualidades que eram/são possuidoras, pureza e amor ao próximo, valores essenciais a visão liberal do poder da escola como uma das únicas alternativas de promoção da igualdade (ALMEIDA, 2004). Os professores entrevistados reforçam esta visão, ao afirmar que as meninas tinham mais “jeito" para ensinar os menores. 
Os meninos foram citados para os trabalhos nos arredores da escola e na horta. Essa divisão de tarefas na escola reflete a divisão do trabalho nas propriedades agrícolas familiares, nas quais todos os membros da família, desde muito pequenos, contribuem com o trabalho na lavoura e na lida com os animais, tanto da famílias de descendência italiana como alemã. No contexto familiar, as meninas eram educadas para o casamento e desde cedo acompanhavam a mãe nas tarefas domésticas e no aprendizado das "prendas domesticas" (culinária, costura, trabalhos manuais, entre outros). O fim último da educação era prepará-las para o serviço doméstico e para os cuidados com a futura família, sendo reforçado este papel na escola. Nesse sentido, Almeida (2004), resume:

Das mulheres esperava-se a permanência no espaço doméstico, o recato, a submissão, o acatamento da maternidades como a mais elevada aspiração. Dos homens, a atuação no espaço público, do mundo do trabalho, na política, o exercício da liberdade, inclusive sexual, a incorporação dos atributos de proteção e autoridade (p. 73).

Essa condição da educação da mulher também foi evidenciada pelas professoras entrevistadas, que mencionaram o casamento muito cedo e que ao adentrarem na profissão conciliavam as tarefas domésticas com a profissão. Várias mencionam que estudaram após os filhos estarem crescidos, pois necessitavam deslocarem-se para a cidade a fim de frequentar os cursos.

Além das atividades durante o período de aula, os professores relatam que levavam para casa "pilhas de cadernos para corrigir". Esta era uma prática comum, exigida pelas autoridades educacionais, esperada pelos pais e alunos. Além disso, restavam as tarefas burocráticas da escola (diários, matrículas, atas de reuniões, etc.), além do planejamento diário das aulas, comentado por todos os professores entrevistados. A professora Darcy disse: “[...] preparava todas minhas aula de noite com a vela né, então eu ficava até 11 horas da noite, preparava um papel com tudo que ia fazer, classe por classe [...]. Deixava a aula pronta, era pra ser assim”.

O professor Ernesto relatou que seguia as orientações da Secretaria de Educação, que indicava os conteúdos a serem contemplados no planejamento. Ressalta o compromisso do professor de “[...] tornar as aulas mais atraentes possíveis [...] ". Também enfatizou, como os demais entrevistados, que o planejamento do conteúdo poderia ser série ou por tema, com conteúdos/atividades dosados de acordo com o nível de cada turma.

O professor Nilo esclareceu que um planejamento coletivo era desenvolvido nas reuniões de professores das escolas multisseriadas, promovidas pela Secretaria de Educação:

eram feitas mensalmente as reuniões pedagógicas e nessas reuniões pedagógicas era preparado por mês, geralmente no começo do mês era preparado tudo já direcionado pra cada dia do mês [...] todas as atividades eram preparadas lá nos cursos, nos encontros pedagógicas e eram levadas para casa. As vezes nem venciam dar tudo que eles davam, era muito bom auxílio, muito grande e assistência também. 
Ferri (1994) aponta que uma limitação das escolas multisseriadas é o planejamento, pois diariamente eram necessários quatro planos de aula, cada plano para sua respectiva série. Todos os professores entrevistados enfatizaram a importância e a necessidade do planejamento, mas também destacaram a dificuldade. Também está presente a menção ao papel da Secretaria de Educação de orientadora das questões pedagógicas, através dos encontros mensais que reuniam todos os professores das escolas. Esse era considerado um momento importante para sair do trabalho solitário, trocar experiências, conversar sobre os problemas e buscar soluções/orientações conjuntas ou definidas pelo órgão central.

A prova, como instrumento de avaliação, foi citada por todos os professores, sendo aplicadas mensalmente e para cada disciplina. De acordo com Libâneo (1984, p. 10), na prática pedagógica tradicional a avaliação corresponde a verificações que podem ser de curto prazo através de interrogatórios, provas orais (era comum o professor "tomar" a tabuada ou a leitura), resolução de exercícios (no caderno ou no quadro) e de prazo mais longo através das provas escritas agendadas para cada disciplina. Ferri (1994, p. 95) aponta a avaliação na escola multisseriada como uma situação limite, visto que "os professores não conseguem pensar que eles próprios acompanham a criança durante os quatro anos de sua escolaridade e que a avaliação poderia ser um processo contínuo, formativo". A necessidade de aplicar as provas mensalmente tem uma relação com os conteúdos mínimos preestabelecidos, que, "de forma alguma, podem deixar de ser trabalhados porque fará falta na formação da criança, em caso de transferência, etc. A avaliação como um processo seletivo, seriado e imprescindível exige que se cumpra este rol de conteúdos para que não haja dificuldades futuras" (FERRI, 1994, p. 95).

Alguns professores também manifestaram que buscavam fazer uma avaliação mais global do desenvolvimento e aprendizagem dos alunos. O professor Ernesto avaliava através da "prova, também o interesse dele [o aluno], se fazia os trabalho, tudo, tem que avaliar tudo, comportamento, tudo, tudo, tem que avaliar tudo”, referindo-se a uma avaliação mais ampla, para além da prova. A professora Terezinha falou que também avaliava algum trabalho ou tema, mas que o principal era a prova, nas palavras dela “prova mesmo!”. Para a professora Neusa, "tudo era avaliado. Eram feitas avaliações descritivas no final de cada conteúdo. Semanal. [...] Trabalhava bem o conteúdo e prestava a avaliação para ver se os objetivos eram alcançados. Muita tabuada”.

A professora Maria enfatiza a memorização, aspecto central que caracteriza a avaliação tradicional: "tudo decorado, eles tinham que decorar na marra, porque o que que tu tinha, a prova pra avaliação no final do mês, que eles tinha que levar a prova pra casa, o caderno de prova, o caderninho de prova, cada um tem o seu caderninho de prova, então o que que tu davam [...] 
cobrava [...]". Quando percebia dificuldades de um aluno adotava a estratégia de sentá-lo junto com um que dominasse o conteúdo. O professor Ernesto também destacou a importância de um aluno ensinar o outro, além do professor "pular de uma série para outra", para ajudar os alunos.

Ainda sobre a avaliação, a Secretaria de Educação, conforme os diários de classe indicam, atribuía a outro professor a tarefa de elaborar e aplicar um teste aos alunos no final do ano letivo. Como os professores das escolas multisseriadas desenvolviam um trabalho solitário e com pouco acompanhamento pedagógico (normalmente uma reunião mensal na sede da ssecretaria), o objetivo desta avaliação final era verificar se os alunos tinham as condições mínimas para aprovação, além de avaliar o trabalho desenvolvido pelo professor (o que explica a preocupação com as provas mensais). A professora Darcy relatou que foi designada para fazer avaliação em outra escola, enquanto que a professora desta se dirigiu à sua escola para avaliação dos alunos:

“Claro, nos tinha que fazer tudo, fazer a prova, e dizer o que podia passar, sim ou não né”. A avaliação dos alunos pelos pares era uma forma de aliviar o trabalho da Secretaria de Educação e não deixar a responsabilidade da avaliação final somente ao professor da turma. Podemos dizer que era uma espécie de "controle" do trabalho do professor. Ao final do ano os professores sabiam que esta prova iria dizer o que ensinou ou não, portanto cabia a eles somente trabalhar para um resultado satisfatório ao final do ano letivo.

Os depoimentos evidenciaram o que outros autores também discutem (FERRI, 1994; BARROS, 2005; SANTOS, 2015; OLIVEIRA; OLIVEIRA, 2015; entre outros) as dificuldades encontradas nas turmas multisseriadas de conciliar os conteúdos para cada série e a distribuição do tempo em sala de aula para o ensino de cada série e para as demais tarefas que cabiam ao professor. Nesse sentido, Molinari (2009, p. 1 apud SANTOS, 2015, p. 75) expõe sobre a atuação do professor e as dificuldades da organização do planejamento e do tempo escolar:

O maior problema é organizar o tempo didático. Quando se deparam com crianças de várias séries ou ciclos, com diferentes necessidades de aprendizagem, dividindo o mesmo espaço e a atenção deles, os docentes pensam que a solução é fazer planejamentos distintos para cada grupo. Porém essa nunca foi uma estratégia eficiente, pois o professor, durante a aula, precisa correr de um lado para o outro tentando atender a todos e, obviamente, ele não dá conta de acompanhar o desenvolvimento dos trabalhos. Se tiver de optar por dar mais atenção a um determinado grupo, certamente se dedicará aos que estão em fase de alfabetização, deixando os outros com atividades fáceis de executar para o nível deles - não demandando a intervenção docente -, o que não lhes propicia a construção de conhecimento.

Frente o exposto, podemos compreender que a dificuldade na organização da sala de aula e do tempo diante das diferentes séries está relacionado com a prática de transpor a realidade da classe seriada para a multissérie. Não necessariamente se pensou em uma organização diferenciada, que 
rompesse com a lógica da fragmentação e do modelo escolar urbano. O planejamento série por série foi o usual e compatível também com a orientação da Secretaria de Educação, apesar dos professores reconhecerem o desgaste frente a quantidade de trabalho a ser realizado. Também as condições de trabalho do professor eram prejudicadas pela falta de materiais didáticos, pela limitação ao quadro, aos poucos livros didáticos ou materiais similares e a cópia no caderno como os principais recursos didáticos.

\section{Considerações finais}

O Brasil, a partir da década de 1930, vive a transição de uma modelo econômico agrárioexportador para uma sociedade de base urbano-industrial. Essa realidade consolida-se nas décadas de 1950-1960. Nesse contexto, a educação passa a ser concebida como necessária a uma quantidade maior de pessoas, pois deveria atender a qualificação imediata de mão de obra para a indústria. Historicamente a educação atendeu as elites brasileiras e as oportunidades estiveram concentradas no meio urbano. Para o meio rural a escola nunca foi considerada importante, devido à tradição de que para produzir no trabalho agrícola o estudo é desnecessário. Nessa lógica, o pouco acesso à educação vinculou-se a existência de escolas isoladas multisseriadas para atender a necessidade de alfabetizar os sujeitos campesinos, numa lógica assistencialista e com o objetivo de mantê-los no campo. Dessa forma, estas instituições constituíram-se na opção para atender a esta população historicamente excluída da escola.

As escolas multisseriadas no Brasil carregaram a visão negativa de uma escola de segunda categoria, a "escolinha", decorrente das condições relacionadas ao isolamento devido a distância e a dificuldade de acesso dos alunos e dos professores, as dificuldades impostas pelas condições de infraestrutura, falta de professores ou professores não habilitados que viram-se diante do desafio de ensinar alunos de diferentes séries, em um mesmo espaço, com limitados recursos didáticos, humanos e financeiros.

A presença do professor leigo nas escolas rurais era comum no Brasil no período estudado e este, geralmente, iniciava a docência a partir de convites das autoridades para atuar na comunidade rural em que residia ou que poderia residir. Esta escolha estava vinculada ao seu reconhecimento social como capaz de assumir o papel de ensinar as crianças da comunidade.

A formação de professores leigos é uma dos aspectos previstos no Decreto-lei de 1946, o que demonstra a realidade do Brasil em relação à carência profissionais para o ensino primário. Aos professores leigos era oferecido o curso de $1^{\circ}$ ciclo, de Grau Ginasial (formava os regentes de ensino), que permaneceu inalterado com a vigência da primeira LDB a partir de 1961. Constatamos, que em 
Concórdia, a forma de oferta do Curso Ginasial ocorreu em cursos de férias e através de ensino a distância, no qual os professores recebiam o material de estudo e prestavam provas presenciais no Colégio São José que oferecia o curso Normal presencial. Estas formas de oferta possibilitaram a continuidade da formação devido as dificuldades de deslocamento das comunidades para a zona urbana do município. Os professores consideraram fundamental fazer este curso, que possibilitou, mais tarde, a continuidade da formação no $2^{\circ}$ Ciclo (formava os professores primários), conforme a Lei n. 4024/61 ou no Curso de Magistério que, através da lei 5.692/71, definiu a habilitação de $2^{\circ}$ grau como formação mínima para o ensino de $1^{\mathrm{a}}$ a $4^{\mathrm{a}}$ série do $1^{\mathrm{o}}$ grau.

Os depoimentos dos professores evidenciaram a importância dos mesmos, não somente como o "professor, professora da escola", mas como um ponto de referência, participando diretamente da vida da comunidade e auxiliando nas suas demandas. Revelaram o que os levou à docência, enfatizando a formação inicial precária e as dificuldades para uma formação mais adequada, a fim de enfrentar os desafios da profissão.

A maioria dos entrevistados iniciou a atuação no magistério sem formação específica, realizando os cursos posteriormente. Contribuía com a formação dos professores leigos os encontros mensais, destacados como fundamentais, que eram promovidos pela Secretaria de Educação, para orientações, troca de experiências e planejamento das aulas. Nos depoimentos, os professores mencionaram que ao ministrar as aulas aprendiam, percebiam as falhas e buscavam melhorar o ensino a partir de seus conhecimentos e das condições disponíveis (por exemplo, materiais didáticos). Estes professores manifestam a concepção de que a formação é um processo contínuo, que ocorre ao longo de toda uma vida, e não apenas num dado momento ou lugar. A profissão exige um contínuo construir-se como docente (PAIM, 2005).

A organização da escola multisseriada imitou a escola seriada, ou seja, os alunos são divididos em séries e ao professor cabe disponibilizar os conteúdos/atividades e distribuir o tempo para o atendimento de cada uma. Essa condição é vista, historicamente, bem como pelos professores pesquisados, como um aspecto negativo, ou que dificulta o ensino. Para enfrentar as dificuldades, a busca de alternativas estiveram ancoradas no modelo da seriação, de forma a viabilizar a sua manutenção, mas sem alteração da organização e das condições de infraestrutura destas escolas. Nesse sentido, a organização do ensino e do currículo esteve pautado no atendimento de cada série e na aprendizagem individualizada.

Diante dos inúmeros desafios, os professores buscavam estratégias para minimizar as dificuldades e organizar sua atuação que, além das atividades didático-pedagógicas, somava-se às tarefas de limpeza, merenda e organização, além da documentação escolar que deveria manter 
atualizada para prestar contas à Secretaria de Educação. O professor constituiu-se como um profissional multitarefas e polivalente, a começar pelo papel principal de ensinar tantas crianças, de diferentes idades, séries e níveis de aprendizagem, simultaneamente. Ao assumir, tinha ciência das várias frentes de atuação e de que a escola dependia, quase exclusivamente, dele próprio, para cumprir seus objetivos. Essa era a realidade que o professor se deparava, movido pelo compromisso de fazer o melhor trabalho possível, nas condições objetivas que se apresentavam, um trabalho permeado de inquietações e busca de soluções para os problemas.

O trabalho dos professores, no período estudado, caracterizou-se, no geral, pela prática pedagógica tradicional, em que predominaram as aulas expositivas, os exercícios, a memorização e a avaliação através de provas. Os professores não questionavam os conteúdos prescritos (listas) e o sua validade ou adequação à realidade escolar. Era necessário cumprir o plano de ensino e o planejamento do mês, pois também estava sujeito ao controle da Secretaria de Educação. Nesse sentido, Ferri (1994) enfatiza que apesar do professor se considerar-se solitário na classe multisseriada, era somente uma solidão física, pois sua ação pedagógica era controlada pela própria "organização" da escola e pela hierarquia que advém da Secretaria de Educação através dos supervisores e orientadores. Ainda, a avaliação dos alunos pelos pares, no final do ano letivo, era uma forma de controle do trabalho do professor, afinal a prova (elaborada pelo colega designado), baseada nos conteúdos prescritos, era um instrumento para aferir o trabalho desenvolvido durante o ano letivo.

Um aspecto considerado positivo é a diversidade presente nestas escolas, pois, apesar da organização seriada (cada fila uma série), havia um processo de interação entre as diferentes séries, e nessas condições ocorria a aprendizagem dos conhecimentos básicos do ensino primário. Assim, a escola cumpria o papel esperado pelas famílias - a alfabetização dos filhos -, mesmo diante da carência de materiais didáticos básicos e dos limites da formação dos professores que, cotidianamente buscavam superar os desafios a partir das condições objetivas que a prática social oferecia. Por trás das dificuldades, os professores destacaram aspectos pedagógicos positivos relacionados ao auxílio mútuo entre os alunos, às relações de convivência, ao trabalho colaborativo e solidário para a execução das tarefas de organização do ambiente escolar, que contribuía para a educação dos alunos e a valorização da escola perante a comunidade.

Por fim, enfatizamos que a trajetória profissional e as práticas educativas dos professores das escolas multisseriadas merecem ser sistematizadas para a compreensão deste espaço, como conhecimento fundamental à formulação e desenvolvimento de políticas públicas de formação de professores, organização curricular e materiais didáticos para a realidade destas escolas que ainda estão presentes, em muitos espaços, na educação brasileira. 


\section{Referências}

ALMEIDA, Jane Soares de. Mulheres na educação: missão, vocação e destino? A feminização do magistério ao longo do século XX. In: SAVIANI, Dermeval et al. (org.). O legado educacional do século XX no Brasil. Campinas: Autores Associados, 2004. p. 59-107.

AMADOR, Milton Cleber Pereira. A colonização na pequena propriedade familiar pelo descendente de imigrante e o desenvolvimento socioeconômico de Concórdia (1920 a 1960). Concórdia: Fundação Municipal de Cultura; Gráfica Sul Oeste, 2015.

ARROYO, Miguel. Por uma educação do campo. Petrópolis: Vozes, 2005.

AUGUSTO, M. H. Professor leigo. In: OliveIRA, D. A.; DUARTE, A. M. C.; VIEIRA, L. M. F. Dicionário: trabalho, profissão e condição docente. Belo Horizonte: UFMG/Faculdade de Educação, 2010. Disponível em: https://gestrado.net.br/wp-content/uploads/2020/08/340-1.pdf. Acesso em: 15 jun. 2019.

BARROS, Oscar Ferreira. A organização do trabalho pedagógico das escolas multisseriadas: indicativos de saberes pedagógicos de resistência educacional no campo. In: HAGE, Salomão Mufarrej (Org.). Educação do campo na Amazônia: retratos de realidade das escolas multisseriadas no Pará. Belém: Editora Gutemberg, 2005. p. 163-195.

BRASIL. Decreto-lei n⿳0 8.530, de 2 de janeiro de 1946. Lei Orgânica do Ensino Normal. Brasília: Câmara dos Deputados. Disponível em: <https://www2.camara.leg.br/legin/fed/declei/19401949/decreto-lei-8530-2-janeiro-1946-458443-publicacaooriginal-1-pe.html>. Acesso em: 23 maio 2019.

BRASIL. Lei no 4.024, de 20 de dezembro de 1961. Fixa as Diretrizes e Bases da Educação Nacional. Brasília: Câmara dos Deputados. Disponível em: <https://www2.camara.leg.br/legin/fed/lei/19601969/lei-4024-20-dezembro-1961-353722-publicacaooriginal-1-pl.html>. Acesso em: 23 maio 2019.

BRASIL. Lei no 5.692, de 11 de agosto de 1971. Fixa Diretrizes e Bases para o ensino de $1^{\circ}$ e $2^{\circ}$ graus, e dá outras providências. Disponível em: <https://www2.camara.leg.br/legin/fed/lei/1970-1979/lei-569211-agosto-1971-357752-publicacaooriginal-1-pl.html>. Acesso em: 25 maio 2019.

CARDOSO, Maria Angélica. A organização do trabalho didático nas escolas isoladas paulistas: 1893 a 1932. 2013. 259f. Tese (Doutorado em Educação) - Faculdade de Educação - Universidade Estadual de Campinas. Campinas, 2013.

COMASSETTO, Carlos Fernando et al. História de Concórdia do período anterior a sua emancipação. In: ZOTTI, Solange Aparecida. (org.). História faz história: contribuições ao estudo da história regional. Concórdia: Universidade do Contestado, HISED, 2006. p. 149-174.

CONCÓRDIA. Lei $\mathbf{N}^{\circ}$ 3699, de 14 de dezembro de 2005. Altera denominação de escolas isoladas municipais. Concórdia: Câmara Municipal, 2005. Disponível em: https://leismunicipais.com.br/a/sc/c/concordia/lei-ordinaria/2005/370/3699/lei-ordinaria-n-3699-2005altera-denominacao-de-escolas-isoladas-municipais?q=3.699. Acesso em: 25 maio 2019.

FERREIRA, Antenor Geraldo Zanetti. Concórdia: o rastro de sua história. Concórdia: Fundação Municipal de Cultura, 1992.

FERRI, Cássia. Classes multisseriadas: que espaço escolar é esse? 1994. Dissertação (Mestrado em Educação) - UFSC, Florianópolis, 1994.

IBGE - Instituto Brasileiro de Geografia e Estatística. Censo Demográfico de 1960 - Santa Catarina. Rio de Janeiro: 1968. (VII Recenseamento Geral do Brasil, Série Regional, v. I, Tomo XV- 2a Parte). Disponível em:

https://servicodados.ibge.gov.br/Download/Download.ashx?http=1\&u=biblioteca.ibge.gov.br/visualizacao /periodicos/68/cd_1960_v1_t15_p2_sc.pdf. Acesso em: 25 maio 2019. 
IBGE - Instituto Brasileiro de Geografia e Estatística. Sinopse preliminar do censo demográfico:- 1970. Santa Catarina. Rio de Janeiro, 1971. (VIII Recenseamento Geral). Disponível em:

https://servicodados.ibge.gov.br/Download/Download.ashx?http=1\&u=biblioteca.ibge.gov.br/visualizacao /periodicos/311/cd_1970_sinopse_preliminar_sc.pdf. Acesso em: 25 maio 2019.

IBGE - Instituto Brasileiro de Geografia e Estatística. Sinopse Preliminar dos resultados demográficos segundo as Unidades da Federação e os Municípios. Rio de Janeiro: 1941. (Recenseamento Geral do Brasil. Realizado em $1^{\circ}$ de setembro de 1940). Disponível em:

https://servicodados.ibge.gov.br/Download/Download.ashx?http=1\&u=biblioteca.ibge.gov.br/visualizacao /periodicos/314/cd_1940.pdf. Acesso em: 25 maio 2019.

IBGE - Instituto Brasileiro de Geografia e Estatística.VI Recenseamento Geral do Brasil -1950. Estado de Santa Catarina - Censo Demográfico. Rio de Janeiro: 1955. (Série Regional, v. XXVIL, Tomo 1) Disponível em:

<https://servicodados.ibge.gov.br/Download/Download.ashx?http=1\&u=biblioteca.ibge.gov.br/visualizaca o/periodicos/67/cd_1950_v27_t1_sc.pdf>. Acesso em: 25 maio 2019.

IBGE · Instituto Brasileiro de Geografia e Estatística. Estatísticas históricas do Brasil: séries econômicas, demográficas e sociais de 1950 a 1988. 2. ed. Rio de Janeiro: IBGE, 1990. p. 36-37.

LIBÂNEO, José Carlos. Democratização da escola pública: a pedagogia crítico-social dos conteúdos. São Paulo: Loyola, 1984.

MARAFELLI, Cecilia Maria; RODRIGUES, Priscila Andrade Magalhães; BRANDÃO, Zaia. A formação profissional dos professores: um velho problema sob outro ângulo. Cadernos de Pesquisa, São Paulo, v. 47, n. 165, p. 982-997, jul./set. 2017. Disponível em: < https://doi.org/10.1590/198053144293.>. Acesso em: 16 jun. 2019.

MIRANDA, Ângelo Tiago de. Urbanização do Brasil: consequências e características das cidades. Disponível em: https://educacao.uol.com.br/disciplinas/geografia/urbanizacao-do-brasil-consequencias-ecaracteristicas-das-cidades.htm. Acesso em: 25 maio 2019.

OLIVEIRA, Mara Rita Duarte de; OLIVEIRA, Nazareno do Socorro da Silva. Classes multisseriadas: práticas, memórias e formação docente. Revista Margens Interdisciplinar, Abaetetuba, PA, v. 9, n. 12, p. 225-237, 2015. Disponível em: https://periodicos.ufpa.br/index.php/revistamargens/article/view/ 3070/3091. Acesso em: 16 jun. 2019.

PAIM, Elison Antonio. Memórias e experiências do fazer-se professor. 2005. 532f. Tese (Doutorado) Faculdade de Educação, Universidade Estadual de Campinas, Campinas, 2005. Disponível em: http://www.repositorio.unicamp.br/handle/REPOSIP/252728. Acesso em: 15 jun. 2019.

RIBEIRO, Maria Luisa Santos. História da educação brasileira: a organização escolar. 15. ed. Campinas: Autores Associados, 1998.

SÁ, Carolina Figueiredo de; PESSOA, Ana Cláudia Rodrigues Gonçalves. Práticas de alfabetização em turmas multisseriadas: estratégias docentes para lidar com a heterogeneidade de aprendizagens. In: REUNIÃO NACIONAL DA ANPEd, 37., 2015, Florianópolis. Anais eletrônicos [...]. Florianópolis: UFSC, 2015. p. 1-19. Disponível em: trabalho-gt10-4458.pdf. Acesso em: 25 maio 2019.

SANTOS, Willian Lima. A prática docente em escolas multisseriadas. Revista Científica da FASETE, Bahia, p. 71-80, 2015. Disponível em: https://www.fasete.edu.br/revistarios/media/revistas/2015/9/a _pratica_docente_em_escolas_multisseriadas.pdf. Acesso em: 15 jun. 2019.

SAVIANI, Demerval. História das ideias pedagógicas no Brasil. 2. ed. Campinas: Editores Associados, 2007. 
SCHIAVINI, Andréia Cadorin. Alfabetização e letramento nas escolas do campo de Concórdia: o que dizem os cadernos dos alunos do primeiro ano. 2018. 212f. Dissertação (Mestrado em Educação) Programa de Pós-graduação em Educação, Universidade Federal da Fronteira Sul, Chapecó, 2018.

SILVA, Janssen Felipe da et al. Paradigmas da educação do campo: um olhar a partir dos estudos póscoloniais latino-americanos. Revista Reflexão e Ação, Santa Cruz do Sul, v. 22, n. 2, p. 9-38, jul./dez. 2014.

SILVA, Maria Socorro. O movimento da educação do campo no Brasil e seu diálogo com a educação popular e a pedagogia decolonial. Cadernos de Pesquisa: Pensamento Educacional, Curitiba, v. 13, n. 34, p. 77-94, maio/ago. 2018. Disponível em: http://www.utp.br/cadernos_de_pesquisa/. Acesso em: 15 jun. 2019.

SOLIGO, Valdecir; SANTOS, Almir. São José e Olavo: duas escolas, uma história. Concórdia: Sigma Editora, 2005.

SOUZA, Rosa Fátima de Souza. Espaço da educação e da civilização: origens dos Grupos Escolares no Brasil. In: SAVIANI, Dermeval et al. (org.). O legado educacional do século XIX. Campinas: Autores Associados, 2006. p. 33-84. 